\title{
Personal and Personality Development as Basis of Succesful Employee Diversity and Well-Being Management
}

\author{
Šarotar Žižek Simona \\ University of Maribor, Maribor, Slovenia \\ Mulej Matjaž \\ University of Maribor, Maribor, Slovenia \\ IRDO, Maribor, Slovenia \\ Potočnik Amna \\ Maribor Development Agency, Maribor, Slovenia \\ IRDO, Maribor, Slovenia \\ Kalamar Maja \\ University of Maribor, Maribor, Slovenia
}

\begin{abstract}
European Union becomes intensively more integrated. Loosening of the labour market makes organizations in EU encounter increased employee diversity. Employ ee diversity management (EDM) depends on those, who manage diversity and those who are managed. The personal development to the successful EDM. The personality development contributes significantly to the success of EDM providing competitive advantages to organizations by social responsibility, cost management, acquirement of funds, marketing, creativity, problem solving, innovations, flexibility, employees well-being, etc.. DM is complicated; it must include holistic personal and primarily personality development. There for is the propose discussion about interdependence of EDM and well-being. In order to help readers understand that reaching enterprise competitiveness is provided by EDM on basis of personal and personality development of employees. We used desk research, backed by field research on EDM and well-being as a precondition for business success. The main result is connection between EDM and well-being; we detected no texts exposing the links discussed by us here. Practitioners can retrieve suggestion about their management style and process in order to generate related non-technological innovations aimed at promotion of personal development and well-being in their respective units.
\end{abstract}

Keywords: European Union, employee diversity, employee diversity management, well-being, personality, personal development

\section{Introduction}

European organizations encounter greater diversity among their employees, due to increased labour

Šarotar Žižek Simona, M.sc., Senior Lecture, Faculty of Economics and Business, University of Maribor.

Mulej Matjaž, Ddr. Professor Emeritus, Faculty of Economics and Business, University of Maribor, IRDO.

Potočnik Amna, M.sc., Maribor Development Agency, IRDO.

Kalamar Maja, postgraduate Student, Faculty of Economics and Business, University of Maribor.

Correspondence concerning this article should be addressed to Šarotar Žižek Simona, Faculty of Economics and Business, University of Maribor, Razlagova 20, 2000 Maribor, Slovenia. E-mail: zizek@uni-mb.si. 
elasticity and mobility. Employee diversity denotes human characteristics, making them different from each other, and different personality types. This makes employee diversity management (EDM) increasingly important.

EDM includes coordinating, linking and upgrading different characteristics of individuals, aiming to create synergies at work. EDM covers conflict management and harmonization of different characteristics of different people aimed at their holistic synergy. It is complicated and must involve a holistic personal and primarily personality development. EDM provides competitive advantages to organizations through positive effects concerning social responsibility, cost management, acquirement of funds, marketing, creativity, problem-solving, innovations, flexibility, etc. (Treven \& Mulej, 2005, pp. 321-329).

We discuss the situation concerning employment within EU, employee diversity (ED) and EDM. Then, we shall expose impact of EDM, personal and personality development.

\section{Employment in EU Expects Growing Employee Diversity}

EU guarantees its 27 members four types of free movement: (1) persons; (2) goods; (3) services; and (4) capital. Free movement of persons includes the EU nationals' right to freely move to another EU-member state, to be employed and reside there with their family members. Thus, free movement of workers precludes EU-member states from direct or indirect discrimination against EU workers and their families on the basis of nationality in employment-related matters. It also ensures equal treatment as regards public housing, tax advantages, and social advantages (Employment, 2008, p. 112).

Labour mobility between EU-member states is an important element of the European Employment Strategy and at the centre of the Commission's recent job mobility action plan 2007-2010. When EU expanded in 2004 and 2007 the 15 “old” EU-member states worried and feared of having their labour markets flooded by workers from the poorer Central and Eastern European countries.

EU also attracts numerous immigrants from other countries. Therefore, their immigration remains highly important in EU's and member states' agendas. Since 1990s, issues related to international migration, and especially labour migration, have received increasing policy-makers' attention. For European Commission, immigration impacts economy, society, and external relations. Moreover, against the background of ageing European societies and growing labour market needs, demand for immigration in the EU is set to increase over in the future (EC, 2008, p. 43).

The increased elasticity of the labour market, the workers' mobility and immigration to EU, increases ED. Organizations must manage their ED to generate competitive advantages.

\section{Employee Diversity}

\section{Definition of Employee Diversity (ED)}

Literature defines ED variously. We apply the simplest definition: ED exposes characteristics making employees mutually different. Sources of individual variations are complex, but they make two categories: (1) those, over which we have little or no control; and (2) those, over which we have more control (Greenberg \& Baron, 2000; as cited in Treven \& Mulej, 2005, p. 321). Biological characteristics such as race, sex, age, certain physical attributes, family, society, and history, within which we live, form the first group. These factors 
powerfully influence individual identity and directly affect the manner of person's relation to other individuals and groups, at work and beyond. The second group includes characteristics that people can adopt, drop, or modify through conscious choice and deliberate efforts, such as: marital status, political beliefs, geographic location, work background, and education/profession.

Harvey and Bowin (1996, p. 390) define diversity in organizations by following characteristics (see Figure 1): (1) race, gender and ethnic difference; (2) sexual orientation; (3) physical and psychical characteristics; (4) age and education; and (5) religion, values, viewpoints, lifestyle, talents.

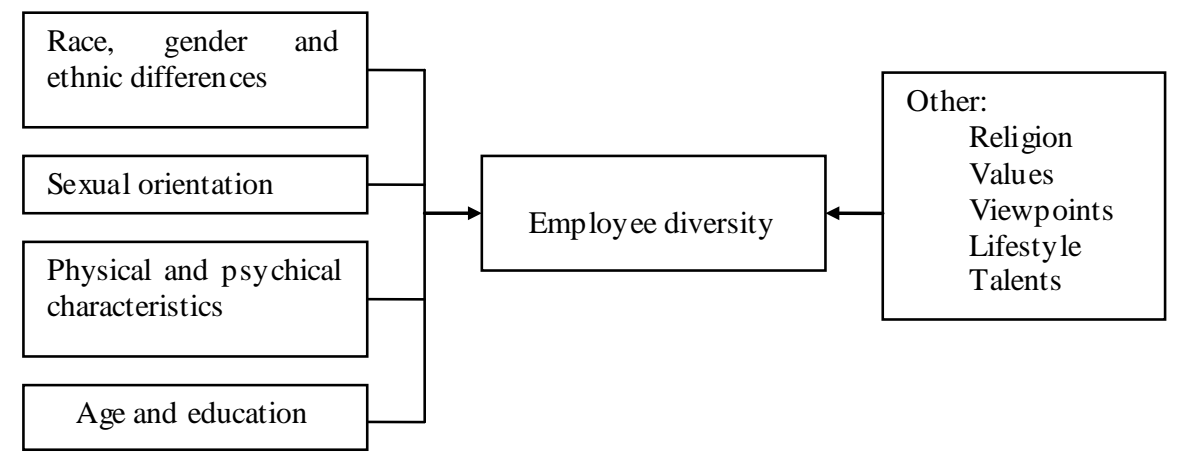

Figure 1. ED characteristics. Source: Harvey and Bowin (1996, p. 390).

Employees of the same age, gender, professional group often show similar patterns of behaviour. Globalization makes organizations more diverse. Therefore the differences between groups become increasingly expressive and lead to problems in EDM. First, we must explain the term EDM (Treven, 2001, p. 101).

\section{State/Categories of Diversity}

Krofič (2008, p. 43) mention the basic and secondary dimensions of diversity. The basic ones (race, ethnic affiliation...) are inborn and have greater influence on a person. They also include key elements of perspective creating or self-image. The secondary dimensions include changing attributes acquired during life.

The diversity experts Gardenswartz and Rowe define four layers of diversity, making individuals differ from each other. The mentioned four stages (see Figure 2) determine individual's personal identity and influence his worldview (Krofič, 2008, p. 43).

(1) The first stage is personality representing characteristics building individual's identity, and they occupy the centre of the diversity cycle;

(2) The second stage represents the internal dimensions conceived as primary dimensions of diversity. They are mostly outside individual's control yet they strongly influence his behavior, relations, expectations, and conclusions about other people;

(3) The third stage consists of external influences perceived as secondary dimensions of diversity. They represent individual differences over which humans have great influence and control. These characteristics significantly impact our acceptance, behaviour and relation. A lack of consciousness about the importance of external dimensions of ED can cause bad feelings at the employer's and customer side;

(4) Therefore the fourth stage includes organizational dimensions such as title of work, position, work location, importance (Hellrigel \& Slocum, 2004; as cited in Treven, 2007, p. 1926).

\section{Personality Types of Employee Personalities}

We explore the individual's personality. Gordon (1996; as cited in Treven, 2001, p. 102) includes in 
personality numerous unique personal attributes, motives, emotions, values, interests, behaviour and talents. These attributes are influenced by inheritance and social, cultural, and family environment.

Psychologists investigated different aspects of personality and explained their influence on behaviour within working environment. The dimensions that we focus on appear in synergies (Treven, 2007, pp. 105-107):

(1) Extroversion-introversion: Jung $(1994,2003)$ classified people in extroverts (with attributes such as sociability, vivacity, entrepreneurial spirit, active and impulsive behaviour, interest in surroundings), and in introverts (unsocial, careful, reserved, behaving considerately, interested in their own experience and their internal, subjective world) (Musek, 1993; Treven, 1998; Udovičič, 2004).

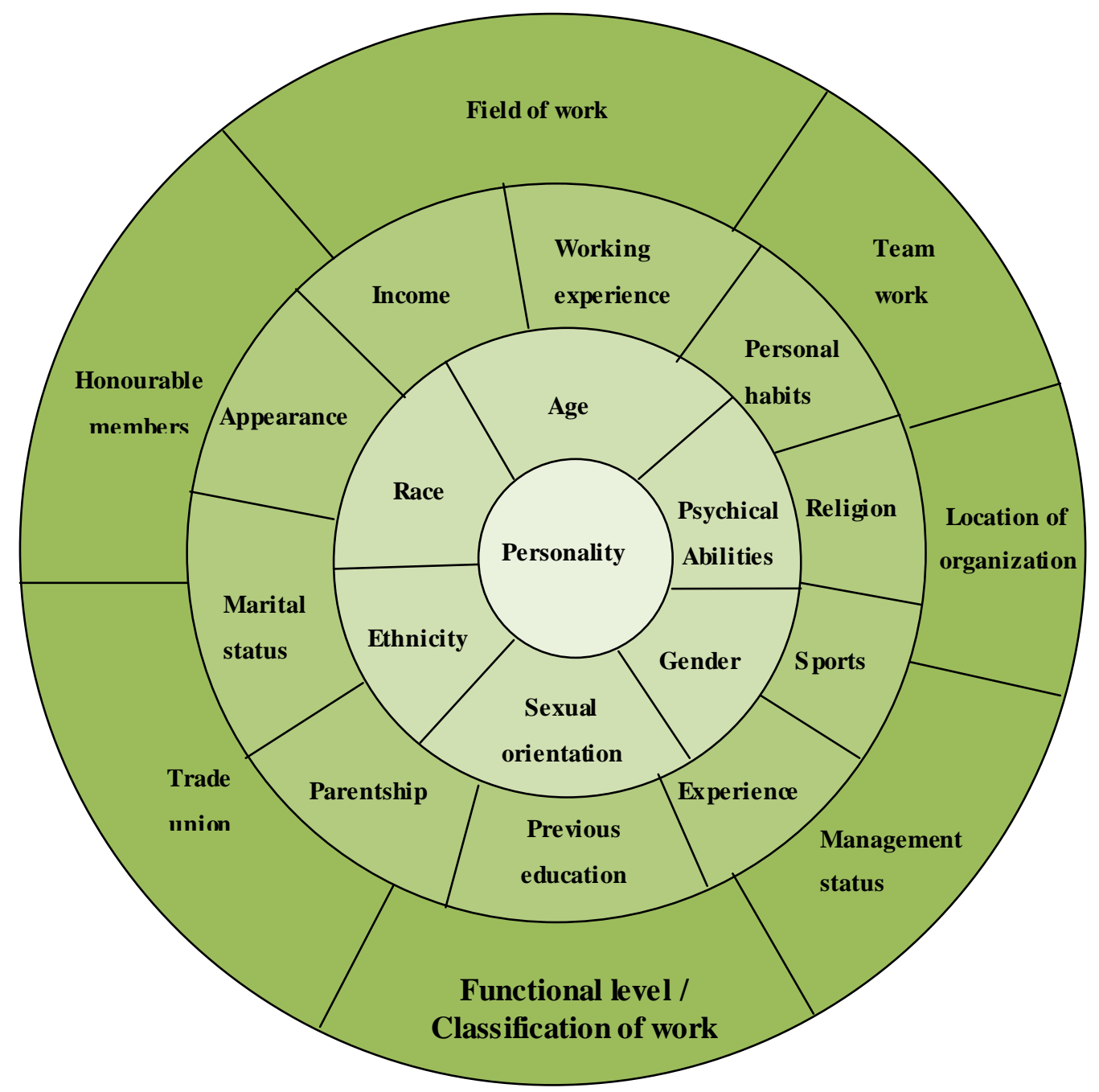

Figure 2. Stages of diversity. Source: Hellriegel and Slocum (2004); as cited in Treven, 2007, p. 1927.

(2) Adjustment to organizational life: All employees must actively adjust to their organization. It depends on employee's personality if this adjustment is succesful. Regarding successfulness of this adjustment, we distinguish three basic groups of personalities (Presthus, 1978):

- The organizationalist: committed to job, identifies strongly with his/her organization, seeks organization's rewards and advancement, emphasizes organizational goals, and avoids controversy; 
- The professional: job-concentrated, tends to view organization's demands as pressure, highly ideological about work values, seeking recognition from other professionals outside the organization;

- The indifferent: works for pay, hardly job-committed.

(a) Authoritarianism: A belief that there should be status and power differences among people in organizations (Staw, 2003; Vecchio, 2000). An authoritarian personality is intellectually rigid, judgmental of others, deferential to superiors, and exploitative of those below, distrustful, and resistant to change. Maslow (1965) said that true authoritarians take advantage of others; the best way to deal with them is to assert your own authority, if possible;

(b) Machiavellianism: Machiavellian (Mach) personality includes many similar traits as the authoritarian one; she is pragmatic, maintains emotional distance, and believes that ends justify means. Such people attempt to abuse others, and seek to form alliances with people in power to serve their own goals;

(c) Bureaucracy: This personality values hierarchy, rule conformity, impersonal and formal relationships. They believe employees should identify with their organization and subordinate their individual preferences to the organizational needs;

(d) Locus of control: Some people believe that they master their own fate (internal). Others see themselves as pawns of fate and believe that what-ever happens to them is due to luck or chance (external). Evidence shows that employees who rate high in externality are less satisfied with their jobs, and less involved in their jobs than internals (Robbins, 1998);

(e) Risk propensity: People differ in their willingness to take chances, too. Individuals with a high-risk propensity make more rapid decisions and use less information in decision-making than low-risk propensity individuals. Managers can use this information regarding specific job demands. In some jobs making rapid decisions and taking risk is useful;

(f) Type A and B personality: People with type-A personality are action- and result-oriented. They exhibit ambition, drive, enthusiasm, and commitment and clearly expect promotions, advancements, and rewards. Type-B persons are more easy-going and rarely demonstrate high levels of emotion (Pettinger, 2002; Kreitner, Kinicki, \& Buelens, 2002). They tend to excel where a more considered approach is required, including attention to the quality of results and output - to give the right answer, not just any answer. Despite of the stated ambition drive, type-B persons tend to achieve the very top, too (Robbins, 1998).

\section{The Second Stage of Diversity}

Besides the personality, as the first stage of diversity, also its second stage matters for our research, presenting internal dimensions as the primary dimensions of diversity. They include employees' values and viewpoints, starting to develop in their early childhood. To recognize the reasons for certain situations, employees should understand the nature and influence of values and viewpoints in their working environment. The values, which are rather stable, refer to the basic principles and to principles that control the principles, beliefs and knowledge (Gordon, 1996; Treven, 2001, p. 108). The individual's standpoints make pre-disposition for response and show positive or negative favour or disfavour, appeal or resistance to each object in his/her environment (Tosi, Mero, \& Rizzo, 2000; Treven, 2001, pp. 108-109).

The second dimension is age. Krofič (2008, p. 46) classifies the generation picture of economically active 
population into four greater generations: (1) veterans; (2) children of welfare; (3) generation X; and (4) generation Y. They differ in many attributes reflecting in everyday life, including career development and work in organizations, working habits, motives, and values.

The next dimension is gender and sexual orientation. Despite big differences between genders, men and women work together, the number of employed women increases. Women are typically more unaggressive, uncompetitive, devoted and preferring their relation over victory; men are more competitive, aggressive, dominant and independent (duPoint, 1997, p. 34). Krofič (2008, p. 47) defines sexual orientation as experience of sexual appeal to the same or opposite gender.

The inner categories of diversity include also race and ethnicity. Ethnicity refers to the culture group by which individuals identify themselves and includes habits, language, religion, nutrition, tradition etc.. Race represents biological, physical differences between people, such as skin colour, eye shape, and body constitution.

The last inner dimension of diversity manifests talents, which are connected with different characteristics. Krofič (2008, p. 47) differentiates between physical (material) and mental (psychical) abilities, making individuals strongly differ.

The external dimensions include: education, experience, income and economic status, geographic location, appearance, personal and sports habits, religion, family issue, career and personal development. The latter is substantial for success of EDM.

\section{Employee Diversity Management (EDM)}

\section{Definition of EDM}

ED and individual differences belong to crucial issues challenging managers in the quest for high performance and organizational competitiveness by EDM. This is true not only in the EU countries but also in the United States and in other countries. Hence: What is EDM? EDM entails enabling people to display their maximum potential, either despite their diversity or on its basis, resulting in their complementary attributes and interdependence. EDM focuses on changing an organization's culture and infrastructure for people to excel (Kreitner et al., 2002). Ann Morrison, an ED expert, studied 16 organizations with successful EDM. Her results uncovered three key strategies for EDM's success: (1) Education; (2) Enforcement; and (3) Exposure.

(1) The education component of EDM strategy has two thrusts: first, to prepare the less-traditional managers for increasingly responsible posts; the other to help traditional managers overcome their prejudices by thinking about and interacting with people of a different sex, ethnicity, etc.;

(2) The enforcement component of EDM strategy addresses diversity-related goals and encourages behavioural innovation;

(3) The exposure to people with different backgrounds and characteristics adds a more personal approach to ED by helping managers learn to know and respect the different ones (Morrison, 1992; Treven \& Šarotar, 2008, pp. 2-3).

The EDM concept in organizations emphasizes appreciation of differences and creating atmosphere in which everyone feels valued and accepted. The success or progress in EDM can be monitored by organizational surveys of attitudes and perceptions. EDM assumes that groups will retain their own characteristics, will shape the company and be shaped by it, creating a common set of values that will strengthen ties with customers, 
enhance recruitment, and the like. Sometimes, EDM is resisted because of fear of change (Schermerhorn, Hunt, \& Osborn, 2004; as cited in Treven \& Mulej, 2007, p. 5).

\section{Approaches to EDM}

Ways of EDM include individual and organizational approaches, different methods and system approach (Treven, 2001, p. 116; Treven \& Mulej, 2005, p. 327).

The individual approach to DM includes two interdependent directions: (1) learning; and (2) empathy. The first is based on gaining professional exper ience, and the second on ability to understand feelings and emotions of the others (Treven, 2007, p. 1927). Learning is especially important for managers who are often not willing to cope with diversity. Goleman (1997) defines the empathy as perceptivity of an individual for other people's feelings, needs and concerns. It is the ability of putting oneself in others' shoes and seeing the world from different viewpoints.

Kandola (1995) and Treven (2001, p. 118) find that the contemporary organizational structures do not always suit EDM. After Schermerhorn et al. (2004) and Treven (2007, pp. 1928-1929) a new type of organization must be formed, in which the following criteria shall be considered: (1) organizational vision; (2) co-operation of the top management; (3) estimation of needs; (4) accuracy of goals; (5) clear responsibility; (6) effective (internal and external) communication; (7) reconciliation of activities; (8) appraisal; and (9) innovative culture. The organizations following such strategy can better accomplish different initiatives, referring to ED.

Mulej and Treven (2005, p. 328) assert that DM manages conflicts and reconciliation of different people to the synergy of jointly operation; this complex activity cannot succeed without using system thinking. They suggest Mulej's Dialectical Systems Theory as a suitable methodological base for system consideration about EDM.

Organizations can also use the following methods and activities for EDM (Treven, 2001, p. 119): (1) training programs in EDM; (2) multicultural groups; and (3) senior ED manager.

Treven (2006, p. 363) finds:

Training programs concerning EDM are frequent in organizationsand can include tests showing what knowled ge about other cultures the particip ants have. Games, videos, exercises stimulate discussion. The program concludes with discussion about ED efforts in the participants' own organizations. The time required for the program varies from a few hours to a few days. The major focus of such training is raising awareness and sensivity to diverse issues of EDM.

The employees from different cultural backgrounds who meet regularly form the multicultural groups. They discuss their attitudes, feelings, and beliefs about cultural differences and how they influence behavior in work settings (Treven, 2006, p. 363).

Treven (2001, p. 120) states that the organizations should create a senior manager position responsible for all ED initiatives. They develop compensation and reward programs tied to achieving ED goals, language training, mentoring programs, cultural advisory groups, and corporate social activities that celebrate ED.

\section{Impact of EDM on Competitive Advantage}

Organizations with effective EDM may gain competitive advantages. They stem from process by which the EDM affects organizational behaviour and effectiveness. Effective EDM can result in: (1) lower costs and improved employee attitudes; (2) recruiting efforts; (3) increased sales, market share and corporate profits; (4) 
better group problem-solving; (5) implementing the values of fairness and respect for all people; and (6) innovation and creativity add the favourable effects on social responsibility. The relationship between EDM and each of these outcomes is briefed elsewhere (Cox, 2001; Treven \& Šarotar, 2008; Moss-Kanter, 1983; Larkey, 1996).

\section{Impact of EDM on Humans Well-Being}

Well-being is a complex construct. Its meaning is contested and its key distinction delimits: (1) hedonic and eudaimonic well-being; and (2) objective and subjective measures (SDRN, 2005, p. 4).

One knows also the relative well-being, depending on one's comparison with people playing important roles in one's life (Revkin, 2005). Diener and Seligman (2004, p. 25; as cited in Prosenak \& Mulej, 2007a, p. 3) showed the following partial formula for high well-being:

Living in a democratic and stable society that provides material sources to meet needs, having supportive friends and family, rewarding and engaging work and adequate incomes, being reasonably healthy and having treatment available in case of medical problems, having important goals related to one's values, and philosophy or religion providing guidance, purpose and meaning to one's life. Here we address subjective well-being.

\section{Subjective Well-Being}

Subjective well-being (SWB) is the main topic in positive psychology (Musek \& Avsec, 2006, p. 51). Diener and Seligman (2004) define SWB as the evaluation of one's life taking into account one's positive emotions, work, life satisfaction and meaning. For Musek and Avsec (2002, p. 10) SWB is the main notion, combining many evaluations, tackling the individual's cognitive and emotional, general and more specific life.

The concept of SWB covers three components: (1) the positive emotions and humors; (2) the absence of negative emotions and humors; and (3) the evaluation of life satisfaction (Musek, 2005, p. 178). The second factor of SWB tackles the emotional aspect of well-being, including two independent components-positive and negative effect. A measuring device had to be built for measuring the three above mentioned components in order to provide the requisite information. Watson, Clark and Tellegen (1988; as cited in Musek, 2005, p. 178) mention that positive and negative affection (PA and NA) is measured by numerous instruments and mostly the PANAS questionnaire (Positive Affect Negative Affect Scale) is used.

Diener and Biswas-Diener (2000; as cited in Musek, 2005, p. 179) claim, that the dimensions such as optimism and the feeling of fulfillment should also be included in the concept of well-being. Therefore, we see the emotional components of SWB, which are composed of positive and negative effects, and cognitive components, which are composed of, for instance, life satisfaction. Although the mentioned components correlate, they differ (Diener \& Biswas-Diener, 2000; as cited in Musek \& Avsec, 2002, p. 12). Anyway, it is not about money only. Diener's research indicates that there is no sole determinant of SWB. Some conditions seem to be necessary for high SWB (e.g., mental health, positive social relationships), but they are not, in themselves, sufficient to cause happiness (Eid \& Larsen, 2008, p. 5).

According to Diener and Seligman (2004, p. 1), a growing individual's income is increasingly less relevant for growth of well-being, and interpersonal relations and satisfaction at work are increasingly relevant. As important non-economic indicators of social well-being the social capital, democratic management and human rights are mentioned, while at work non-economic factors impact both satisfaction and profitability. Diener and 
Seligman (2004, p. 1) claim that the expected (economic) results are most often impacted by well-being and not vice versa. They detected that people at the top of the well-being scale have more income and more success at work as those in the lower region of the scale. Satisfied employees are better co-workers and therefore help their colleagues in various ways. Furthermore, people with more well-being have better social relations. They are more likely to get married, stay married, and have a successful marriage. And finally, well-being is also connected with health and longer living, but the connections between them are only partially understood. Therefore a high well-being is not precious only in the context of well-being, and it can also be economically useful.

These facts show that information from monitoring of well-being at the organization and state levels is necessary for it to belong to the main topics for management, and accurate measuring of well-being provides a basis of such a policy (Diener \& Seligman, 2004, p. 1). Authors suggest that measuring of well-being, requires positive and negative emotions, commitment, purpose and meaning, optimism, trust, and a wide concept of a full life as variables. At the same time they stress that for the measuring of well-being researches must cover social conditions, income, physical health, mental disorders and social conditions. James (2007) warns that the border between well-being and the end of motivation because of one's affluence combined with complacency is not objective, but subjective.

One could add that on this basis one should monitor SWB, it supports humans' creative work and cooperation, which can then improve the objective and personal well-being. Hornung (2006; as cited in Prosenak \& Mulej, 2007b, p. 6) also finds: happiness is a humans' constant goal and comprehensive synergetic indicator of comprehensive well-being, good performance, physical, psychological, and social health. Hornung (2006, pp. 334-337; as cited in Prosenak, Mulej, \& Snoj, 2008, p. 6) states that for the good well-being the following needs should be met: material, informational and, at the level of individuals, psychological, security, needs for freedom and action, adaptability, efficiency, and needs for responsibility.

In recent y ears, a form of well-being in addition to SWB has emerged from theorists such as Deci and Ry an (e.g., Ryan \& Deci, 2000, 2001) and Ryff (1989) based on the idea of universal human needs and effective functioning. These approaches are labeled "psychological well-being” and are based in part on humanistic theories of positive functioning. (Diener, Witz, Biswas-Diener, Tov, Dim-Prieto, Choi, \& Oishi, 2009, p. 251)

\section{Psychological Well-Being}

The literature on defining positive psychological functioning includes many perspectives such as Maslow's (1968) conception of self-actualization, Rogers's (1961) view of the fully functioning person, Jung's (1933) formulation of individuation, and Allport's (1961) conception of maturity (Ryff, 1989, p. 1070).

A further domain of theory for defining psy chological well-being follows from life span developmental perspectives, which emp hasize the differing challenges confronted at various phases of the life cycle. Included here are Erikson's (1959) psychological stage model, Buhler's basic life tendencies that work toward the fulfillment of life (Buhler, 1935) and descriptions of personality change in adulthood and old age.

Musek (2005, p. 175) states that Jahoda (1958) has been probably the first author, who has, researching the positive psychic health, analysed the existing scientific literature on variables related to normal, optimal psychic activity on one hand and pathologic psychic activity and emotional functioning on the other hand. She was particularly interested in optimal functioning in respect of content and not only as an absence of a negative behaviour. 
All of these insights are bases of a multidimensional model of well-being. Ryff and Keyes (1995, p. 720) included in the model of well-being six distinct components of positive psychological functioning. In combination, these dimensions encompass a breadth of wellness that includes positive evaluations of oneself and one's past life (self-acceptance), a sense of continued growth and development as a person (personal growth), the belief that one's life is purposeful and meaningful (purpose in life), the possession of quality relations with others (positive relations with others), the capacity to manage effectively one's life and surrounding world (environmental mastery), and a sense of self-determination (autonomy).

\section{Implications of Well-Being and Information About It}

Kahneman and Krueger (2006, p. 22) mention that acceptance of self-reported measures of SWB, despite many caveats that subjective measurement requires, could profoundly impact economics:

(1) Subjective measures of well-being would enable welfare analysis in a more direct way that could usefully complement the traditional welfare analysis;

(2) The currently available results suggest that those interested in maximizing society's welfare should shift their attention from emphasis on increasing consumption opportunities to increasing social contracts;

(3) Focus on SWB could shift the emphasis from the importance of income in determining a person's well-being tow ard the importance of person's rank in society.

Although life satisfaction is relatively stable and displays considerable adaptation, it can be affected by changes in the allocation of time and, at least in the short run, by changes in circumstances.

Connection between differences in SWB and economic growth is crucial. Inglehart (1996, p. 518; as cited in Tomer, 2002, p. 29) mentions that country's change from poverty and scarcity to a productive industrial country increases its SWB dramatically. After a threshold, economic growth no longer seems to increase SWB significantly. Inglehart (ibid) found that nations that had once made narrow economic achievement their highest priority became economically secure and now prefer non-economic, life-quality considerations, such as self-expression.

Many studies indicated significant life benefits for people with high SWB; e.g., individuals reporting high SWB had stronger social relationships than less happy individuals (Diener/Seligman 2002). In longitudinal studies, people with higher levels of SWB were more likely to be married at a later measurement (Marks \& Fleming, 1999; Lucas, Clark, Georgellis, \& Diener, 2003). A high individual SWB is a strong predictor of marital satisfaction (Glenn \& Weaver, 1981). At work, employees with higher dispositional positive affect receive higher supervisor's ratings and better pay (Diener et al., 2001). In stressful circumstances, positive affect supports effective coping with problems and overall outcomes (Fredrickson \& Joiner, 2002). High SWB is associated with less suicidal ideation and behaviour (Diener \& Seligman, 2002).

Thus, SWB is related to successful outcomes in a variety of life domains. People with high levels of SWB are more successful in relationships, more successful on the job, and better equipped to successfully cope with stress (Pavot \& Diner, 2004, p. 116). Therefore organizations initiated intervening strategies for providing prime quality of work-life to enhance well-being of employees on job to attain higher productivity, improve performance, and increase retention of potential employees (Garg \& Rastogi, 2009, p. 1).

SWB is important for several reasons, therefore interventions to increase SWB matter: it feels good to 
volunteer more, have more positive work behavior, and exhibit other desirable characteristics (Diener et al., 2002, p. 69). Few direct intervention efforts have been implemented. This requires programs (Fordyce, 1977) or examples (Pavot \& Diener, 2004, pp. 129-130) designed to boost people’s happiness. Kasser and Sheldon (2009, p. 243) propose that businesses consider the possibility of time affluence as an alternative model for improving employee well-being and ethical business practice.

Monitoring of well-being at the organization and country levels provides the necessary information for well-being to become crucial in strategy creation; accurate measuring of well-being forms its basis (Diener \& Seligman, 2004, p. 1). SWB, which supports people's creative work and cooperation leading to an increased objective and personal well-being, should be monitored on this basis.

The personality, personal and, as its essential element, personality development are highly important for a successful EDM. We discuss them now.

\section{Personal Development}

\section{Personality}

Personality can be discussed from different viewpoints: legal, philosophic, psychological, economic, etc.. Therefore definitions of personality abound.

Personality is an internal dynamic organization of psychophysical systems creating individual's characteristic pattern of behaviour, thinking and feeling. To Carver and Scheier (2000, p. 5) personality expresses consistency, internal reciprocity and personal characteristics.

Personality is also an integration of those systems or habits, which represent the individual's adjustment of own attributes to the environment (Wilderdom, 2007).

The newer definitions share three characteristics of personality: unity or integrity (we do not have in mind singular psychical processes, but an individual as a whole), uniqueness or particularity (the attributes of various individuals both differ and connect) and relative consistency in behaviour as a consequence of unity and originality of each single personality (Rot, 1996, pp. 6-7).

Humans develop their personalities (Musek, 2005, p. 176). The personality's development reflects gradually increasing differentiation of living space, the person in particular, and on the other hand their increasing integrity and organization and also means increasing of requisite holism of person. That means that one's personality changes throughout life and evolves new characteristic features. One speaks of individual personal development.

\section{Personal Development, Its Components, Basic Factors and Its Impact on the Development of Organizations}

Authors define personal development differently. We shall use Možina's definition (1984, p. 88): Personal development is a permanent process that starts before entering school, and continues throughout life, when one chooses profession and occupation. Later on one asks oneself about chances of development during the working period and after retirement.

Various political, cultural, economic and social factors, psycho-emotional experiencing of environment and life and its physical and intellectual efficiency, and conceptions of oneself and others influence one's development. Here we should stress the holism of personal development, which results from (Cvetko, 2002, pp. 
47-48):

(1) Professional development: This includes the acquired level of education (formal, informal), i.e., one's formation by education, occupation choice, training and vocational training, ensuring promotion at work;

(2) Personality development: This includes development of personality features in a wider sense, intertwining one's personality characteristics, values, predispositions, motives, viewpoints, interests, forming an integral personality together with one’s skills, knowledge and working results, environment and self-will;

(3) Working development: Called also working career, it means acceptance and success in the chosen activity. It is bound to a certain working environment, in which one works. It reflects success at work within the smaller group to which one belongs. The working development applies to position or function and is affirmed by working results.

All components of personality, professional and working development are intertwined as results of pedagogical, educational, and social factors. Thus, the holistic development of individual means harmonic development of all three components (Merkač, 2005, p. 143). The development of individual, his/her skills, talents and knowledge, essentially influences the organizational progress. Although the development of human resources primarily depends on employees, the organizations re-establish HR development, within which they draw special attention to planning careers, permanent training, information on new work style, and ability of quick response to changes (Merkač, 2005, p. 137).

The following factors impact personality's development (Jereb, 1989, p. 25): (1) healthy organism; (2) inheritance and innateness; (3) environment; (4) operations and activities; and (5) education.

In Možina’s opinion (1984, pp. 87-88) the personal development is influenced by personal factors: (1) knowledge; (2) skills; (3) motives and impulses; (4) personality characteristics, ideas, initiatives, conceptions; group factors: (1) loyalty; (2) attachment; (3) shared objectives. organizational and social factors: (1) decision-making; and (2) work results.

Managers and employees in organizations differ in relation to work. How they respond to their work is not influenced only by their different levels of responsibility, ethical and racial distinction or gender diversity, but also by differences in their individual level of personal development (Treven, 2001, pp. 109-110). To exercise their development, their organizations should strive to build up the highest possible levels of employees' personal development. The personal development significantly marks also the person's career and interdependent jobs, positions and working experience of individuals during their work activity, which follows the changes in preferences, values, experience and behaviour (Bahtijarević-Šiber, 1999, p. 831). Bearing in mind individual and organizational view of career development, the organizations should try to assist their employees' personal development by systematic investing aimed to increase their human capacities. This will bring new ideas, knowledge and experience. For systemic functioning of employees' personal development the following criteria should be fulfilled (Možina, 1984, p. 58): (1) human resources; (2) educational activity; (3) promotional system; (4) remuneration; (5) informing; (6) strategy; (7) management; and (8) adequate organizational culture.

\section{Personality Development}

Today's world is unstructured, settled by qualified individuals; everything turns around intelligence and intangibles, i.e., knowledge streams, emotions and imagination that are no departments within organisation, but 
philosophy (Nordström \& Ridderstråle, 2001, pp. 109, 213). Besides, the world fills people with doubt and inconstancy. People do not feel clear mission, and strive to find it. Neumann (2001, p. 19) says that the modern human, due to one-sidedness of our culture/consciousness, has left the natural side of unconsciousness; human personality stiffened and lost psychical ability of transformation. Therefore the personality development becomes very important as a part of personal development. Thus, cognition about development of personality is crucial for cognition of personality (Musek, 1977, 2006).

\section{Personality Development and Theories of Personality Development}

Personality consists of interdependent human's mental, physical and behavioural characteristics (Musek, 1998, p. 9). It is influenced by one's inheritance factors and own activity; it also produces these factors. Therefore one's personality is not fixed, but evolving (Musek, 1977, p. 205).

Musek (1982, pp. 182-224) classifies theories of personality development in: (1) psychodynamic theories; (2) theories of personality growth; (3) cognitive theories of development; and (4) theories on development of ego, self-identity and self-activity. We use theories of personality growth, partly supplemented by cognitive theories and theories on development of ego, self-identity and self-activity. The existential analysis and Frankl's comprehension of human's development and acting in the world are relevant, too; his concept exposes that the mental motivation is the most important point, one's inner wish to find sense in one's life.

Thus, we define the personality development as learning, how to be in harmony with oneself. Personality development means also, how to accept attitudes and behaviour of others, without feeling indignant, angry and offended. Personality development is connected also with detecting reasons for certain behaviours and exceed boundaries of one's limited conceptions and beliefs, in order to live better with oneself and with others. This ensures: (1) genuine contact with oneself and with others; (2) satisfactory relation, without negative thoughts, feelings and reactions; (3) orientation towards immaterial values; (4) reducing the gulf between one's facts, and ones wants. Brečko (1998, p. 21) considers the personality development as a way of information processing, which enables recognition, understanding and realizing the expectations of different social environments, which one joins. Trojnar (2002, p. 110) says that the development of personal abilities and talents preconditions personality development. He sees herein the only strong support, on which one builds one's personality, grows mentally, and lives a full life.

The personality development brings persons near to their mature personalities, harmonic personality functions, qualifying them for constructive running of their lives (Musek, 1999, p. 18). Maturity does not mean absence of any troubles, problems and conflicts; it is important that we can understand and solve them. Characteristic for mature personalities is:

- Realistic, positive but also critical relation to reality, other people and oneself;

- The ability of planning life, setting life goals and act according to them;

- Striving after personality growth and improvement (Musek, 1998, p. 18);

- Maturity is a complex term. We sees several components of personality maturity (Musek, 1999, pp. 18-19): (1) physical; (2) emotional; (3) cognitive; (4) social; and (5) moral maturity.

There are several techniques to attain a mature personality:

(1) Positive thinking 
It is significant for one's success. Persons with positive attitudes concentrate on solution, seek for good in people, and devote themselves to their capabilities. Persons with negative attitudes concentrate on problems, seek for faults in other people, and devote themselves to their weaknesses.

(2) Concentrating on a present moment

Employees are rarely concentrated on the present moment. Their thoughts lead them into the past or the future. They think about, how they have been affected, cheated, what flops or successes they experienced, what others think of them, etc.. But only the current moment matters. The concentration on the past or the future makes people forget about their current lives.

(3) Managing thoughts

Thoughts are an unstoppable stream of mind. One idea provokes another and the process continues. Successful people, spiritual teachers, yogis, actors, politicians, managers and people control their minds due to their lives. Control over one's mind means configuring one's life and surpassing constantly appearing spontaneous wishes and thoughts. Thus, one decides where to direct one's mind power and when. To feel inner peace one must arrange one's blend of memories, plans, and wishes. Various exercises within yoga or mediation help.

(4) Managing emotions

Permanently one is in certain conditions, changing permanently. When one's frame of mind stays unchanged over time, one feels comfortable. To keep this state, one strives to control one's emotions. This is a livelong activity: emotions must be controlled every single moment. By controlling one’s spirits, one becomes more peaceful.

(5) Development of consciousness

Being aware of one-self, and one's problems, tasks and responsibility, differing from other people, is connected with consciousness. Consciousness is hard to define. One develops consciousness in many ways throughout one's life.

(6) Development of all kinds of human intelligence

Especially important is linking one's personality development with one's intelligence. Knowing and developing several kinds of intelligence matter: they enable the fastest development on a long term. The higher is one's stage of intelligence, the easier are problems and experiences to face.

\section{Conclusions}

Humans in EU become increasingly diverse. There are four layers of diversity. The first stage is personality, consisting of characteristics responsible for individual's identity. The second stage covers the inner dimensions called the primary dimensions of diversity. The third stage is composed of external influences, named secondary dimensions of diversity and representing individual differences which one influences and controls. The fourth stage includes organizational dimensions.

Employers strive to understand diverse employees and assure them the best possible working conditions to stimulate their better productivity and organizational loyalty. Therefore they introduce EDM noticing unique capabilities of employees and supporting their feeling for identity and organizational vision. Efficient EDM matters. It offers organizations competitive advantages; besides favourable effect of social responsibility it also 
influences cost reduction and improved employees' behaviour, increasing sales, market share and profits, group problem-solving, innovativeness, and creativity. Efficient EDM importantly impacts employees’ well-being.

The bases of an efficient EDM are people with their personalities and their personal development. So far, individuals and organisations paid attention mainly to two other essential elements of personal development, i.e., professional and work development. Personality development was ignored. This reflects in quality of relations between employees within organization and with other persons. It is hence essential for EDM. The personality development makes employees more mature personalities. There are numerous ways and techniques for the personality development. All of them matter and work in synergies.

\section{References}

Allport, G. W. (1961). Pattern and growth in personality. New York: Holt, Rinehart \& Winston.

Bahtijarević-Šiber, F. (1999). Management ljudskih potenciala. Zagreb: Golden Marketing Cop..

Brečko, D. (1998). Kako se odrasli spreminjamo. Didakta, Radovljica.

Buhler, C. (1935). The curve of life as studies in biographies. Journal of Applied Psychology, 43, 653-673.

Carver, C. S., \& Scheier, M. F. (2000). Perspectives on personality (4th ed.). Boston: Allyn and Bacon.

Cox, T. Jr. (2001). The challenge of managing diversity. Retrieved March 21, 2008, from http://media.wiley.com/product_data/excerpt/41/07879558/07879551.pdf

Cvetko, R. (2002). Razvijanje delovne kariere. Znanstveno-raziskovalno središče RS, Koper; Fakulteta za družbene vede, Ljubljana.

Diener, E., \& Biwas-Diener, R. (2000). Income and subjective well-being: Will money make us happy? Manuscript submitted for publication.

Diener, E., \& Seligman, M. E. P. (2002). Very happy people. Psychological Science, 13, 81-84.

Diener, E., \& Seligman, M. E. P. (2004). Beyond money, Tovard an economy of well-being. Psychological Science in the Public Interest, 5(1), 1-31.

Diener, E., Nickerson, C., Lucas, R. E., \& Sandvik, E. (2001). Dispositional affect and job outcomes. Manuscript submitted for publication.

Diener, E., Witz, D., Biswas-Diener, R., Tov, W., Dim-Prieto, C., Cho,i D. W., \& Oishi, S. (2009). New measures of well-being. In E. Diener, R. Lucas, U. Schimmack, \& J. F. Helliwell (Eds.), Well-being for public policy (pp. 247-267). New York: Oxford University.

DuPont, K. (1997). Handling diversity in the workplace: Communication is the key. Retrieved Feburary 22, 2007, from http://www.trainingsolutions.com/pdf/handlingss.pdf

Eid, M., \& Larsen, R. J. (Eds.). (2008). Ed Diener and the science for subjective well-being. In The science of subjective well-being (pp. 1-17). New York, London: The Guilford Press, Co..

Erikson, E. (1959). Identity and the life cycle. Psychological Issues, 1, 18-164.

European, C. (2008). Employment in Europe 2008. Retrieved June 2, 2008, from http ://ec.europa.eu/social/main.jsp?catId=119\&langId=en

Fredericson, B. L., \& Joiner, T. (2002). Positive emotions trigger upward spirals toward emotional well-being. Psychological Science, 13, 172-175.

Fordy ce, M.W. (1977). Development of a program to increase personal happiness. Journal of Counseling Psychology, 24, 511-520.

Garg, P., \& Rastogi, R. (2009). Effect of psychological wellbeing on organizational commitment of employees. Journal of Organizational Behavior, VIII(2).

Glenn, N. D., \& Weaver, C. N. (1981). The contributions of marital happiness to global happiness. Journal of Marriage and the Family, 43, 161-168.

Goleman, D. (1997). Čustvena inteligenca: Zakaj je lahko pomembnejša od IQ. Mladinska knjiga, Ljubljana.

Gordon, J. R. (1996). Organizational behavior. New Jersey: Prentice Hall International.

Greenberg, J., \& Baron, R. A. (2000). Organizational behavior. New Jersey: Prentice Hall International.

Harvey, D., \& Bowin, R. B. (1996). Human resource management. New Yersey: Prentice Hall International.

Hellriegel, D., \& Slocum, J. W. Jr. (2004). Organizational behavior. Mason, Ohio: Thomson South-Western. 
Hornung, B. R. (2006). Happiness and the pursuit of happiness. A sociocybernetic Approach. Kybernetes, 35(3/4), 323-346.

Inglehart, R. (1996). The diminishing utility of economic growth: From maximizing security toward maximizing subjective well-being. Critical Review, 10(4), 509-531.

Jahoda, M. (1958). Current concepts of positive mental health. New York: Basic Books.

James, O. (2007). Affluenza-A contagious middle class virus causing depression, anxiety, addiction and ennui. Random House UK Ltd. etc., London, Vermillion, an imprint of Ebury Publishing.

Jereb, J. (1989). Strokovno izobraževanje in razvoj kadrov. Kranj: Moderna organizacija.

Jung, C. G. (1994). Sodobni človek išče dušo. Ljubljana: Julija Pergar.

Jung, C. G., von Franz, M. L., Henderson, J. L., Jacobi, J., \& Jaffẻ, A. (2003). Človek in njegovi simboli. Ljubljana: Mladinska knjiga Založba.

Kahneman, D., \& Krueger, A. B. (2006). Developments in the measurement of subjective well-being. Journal of Economic Perspectives, 20(1), 3-24.

Kandola, R. (1995). Managing diversity: New broom or old hat? International Review of Industrial and Organizational Psychology, 10, 131-167.

Kasser, T., \& Sheldon, K. M. (2009). Time affluence as a path toward personal happiness and ethical business practice: Empirical evidence from four studies. Journal of Business Ethics, 84, 243-255.

Kreitner, R., Kinicki, A., \& Buelens, M. (2002). Organizational behaviour. Berkshire: McGraw Hill Publishing Company .

Krofič, A. (2008). Povezava med raznolikostjo zaposlenih in inovativnostjo podjetja: magistrsko delo. Maribor, Fram.

Larkey, L. K. (1996). Toward a theory of communicative interactions in culturally diverse workgroups. Academy of Management Review, 463-492.

Lucas, R. E., Clark, A. E., Georgellis, Y., \& Diener, E. (2003). Re-examining adaptation and the set point model of happiness: Reactions to changes in marital status. Journal of Personality and Social Psychology, 84, 527-539.

Marks, G. N., \& Flemming, N. (1999). Influences and consequences of well-being among Australian young people: $1980-1995$ (pp. 301-323). Social Indicators Research, 46.

Maslow, A. H. (1965). Motivation and personality. New York: Harper \& Row.

Maslow, A. H. (1968). Toward a psychology of being (2nd ed.). New York: Van Nostrand.

Merkač, S. M. (2005). Osnove managementa zaposlenih. Koper: Fakulteta za management.

Morrison, A. M. (1992). The New Leaders: Guidelines on Leadership Diversity in America, Jossey-Bass, San Francisco.

Moss-Kanter, R. (1983). The change masters. New York: Simon and Schuster.

Možina, S. (1984). Osebni, skupinski in organizacijski razvoj. Kranj: Moderna organizacija.

Musek, J. (1977). Osnove psihologije osebnosti. Ljubljana: Partizanska knjiga.

Musek, J. (1982). Osebnost. Dopisna delavska univerza Univerzum, Ljubljana.

Musek, J. (1993). Osebnost pod drobnogledom. Maribor: Založba Obzorja.

Musek, J. (1998). Človek celostno bitje. Educy: Inštitut za psihologijo osebnosti, Ljubljana.

Musek, J. (1999). Osebnost in zdravje. Ljubljana: EDUCY.

Musek, J. (2005a). Predmet, metode in področja psihologije. Filozofska fakulteta, Oddelek za psihologijo, Ljubljana.

Musek, J. (2005b). Psihološke in kognitivne študije osebnosti. Znanstveni inštitut Filozofske fakultete, Ljubljana.

Musek, J., \& Avsec, A. (2002). Pozitivna psihologija: subjektivni (emocionalni) blagor in zadovoljstvo z življenjem. Anthropos, 34(1/3), 41-68.

Musek, J., \& Avsec, A. (2006). Osebnost, samopodoba in psihično zdravje. Anthropos, 38(1/2), 51-75.

Neumann, E. (2001). Ustvarjalni človek. Ljubljana: Študentska založba.

Nordström, K. A., \& Ridderstråle, J. (2001). Ta novi posel—Funky business, ko zaigra talent, kapital pleše. GV založba, Ljubljana.

Pavot, W., \& Diener, E. (2004). The subjective evaluation of well-being in adulthood: Findings and implications. Ageing International, 29(2), 113-135.

Pettinger, R. (2002). Stress management. Oxford: Capstone Publishing (A Wiley Company).

Presthus, R. (1978). The organizational society. New York: St.Martin’s Press.

Prosenak, D., \& Mulej, M. (2007a). Application of technology to enhancing of (Co) creative (Co-operation and Socially Responsible [52] Action of All in a Society. Murcia. 7th International Conference of Sociocybernetics Technology and Social Complexity, ISA, RC 51 on Sociocybernetics. 
Prosenak, D., \& Mulej, M.(2007b). How can marketing contribute to increase of well-being in transitional (and other) societies? In B. Snoj, \& B. Milfelner (Eds.), 1st International Scientific Marketing Theory Challenges in Transitional Societies Conference, EPF, Maribor, 127-133.

Prosenak, D. M., \& Mulej, S. B. (2008). A requisitely holistic approach to marketing in terms of social well-being. Kybernetes, $37(9 / 10)$.

Revkin, A. C. (2005). A new measure of well-being from a happy little kingdom. The New York Times, Retrieved from http://www.nytimes.com/2005/10/04/scien ce/04happ.html?ex=1171947600\& en=5a41a93522961d05\&ei=5070

Robbins, S. P. (1998). Organizational behavior. New Yersey: Prentice-Hall International.

Rogers, C. D. (1961). On becoming a person. Boston: Houghton Mifflin.

Rot, N. (1996). Obča psihologija. Beograd: Zavod za izdajanje učbenika.

Ryan, R. M., \& Deci, E. L. (2000). Self-determination theory and the facilitation of intrinsic motivation, social development, and well-being. Am. Psychologist, 55, 68-78.

Ryan, R.M., \& Deci, E. L. (2001). On happiness and human potentials: A review of research on hedonic and eudemonic well-being. Annual Review of Psychoogy, 52, 141-166.

Ryff, C. D. (1989). Happiness is everything, or is it? Explorations on the meaning of psychological well-being. Journal of Personality and Social Psychology, 57, 1069-1081.

Ryff, C. D., \& Keyes, C. L. M. (1995). The structure of psychological well-being revisited. Journal of Personality and Social Psychology, 69, 719-727.

Schermerhorn, J. R. Jr., Hunt, J. G., \& Osborn, R. N. (2004). Core concepts of organizational behavior. Wiley, N.J.: Hoboken.

Staw, B. M. (2003). Pschological dimensions of organizational behavior. New Yersey: Pearson Education.

Sustainable Development Research Network. (2006). Wellbeing concepts and challenges. Retrieved from http://www.sd-research.org.uk/wellbeing/documents/FinalWellbeingPolicyBriefing.pdf

Tomer, F. J. (2002). Human well-being: A new approach based on overall and ordinary functionings. Review of Social Economy, LX(1), 23-44.

Tosi, H. L., Mero, N. P., \& Rizzo, J. R. (2000). Managing organizational behaviour. Oxford: Blackwell Publishing.

Treven, S. (2006). The impact of employee diversity management on competitiveness of an organization. V Kickstarting small island enterprise competitiveness Barbados, March 26-28. The University of the West Indies at Cave Hill, Department of Management Studies. 357-368.

Treven, S. (2007). Employ ees aspects of transition. In Potočan, Vojko in Matjaž Mulej. Transition into an Innovative Enterprise (pp. 102-116). Maribor: EPF.

Treven, S., \& Šarotar, Ž. S. (2008). The encouragament of innovativeness through employee diversity management. In Proceedings/4th International Conference An Enterprise Odyssey: Tourism—Governance and Entrepreneurship, University of Zagreb, Faculty of Economics and Business, Cavtat, Croatia, June 11-14, 2008. Zagreb: Faculty of Economics and Business. 205-206.

Treven, S., \& Mulej, M. (2005). Sistemski pristop k obvladovanju raznolikosti zaposlenih v globalnem okolju. Organizacija, 38(7), 321-329.

Treven, S., \& Mulej, M. (2007). The systemic approach to the encouragement of innovativeness through employee diversity management. Kybernetes, 36(2), 144-156.

Treven, S., \& Srića, V. (2001). Mednarodno organizacijsko vedenje. Ljubljana: Gospodarski vestnik.

Treven, S. (1998). Management človeških virov. Ljubljana: Gospodarski vestnik.

Treven, S. (2001). Human resource management in international organizations. Management, 6(1-2), 177-189.

Trojnar, F. (2002). Moč osebne rasti: sezite po uspehu, v osebnem, družinskem in poslovnem življenju. Maribor: Trojnar Consulting.

Udovičič, K. (2004). Metode nematerialne motivacije za inoviranje managerjev v tranzicijskem podjetju (Udejanjanje intrinzičnos ti $v$ inovativnem poslovodenju človeških sposobnosti) (Ph.D. dissertation, University of Maribor, Faculty of Economics and Business, Maribor).

Vecchio, R. P. (2000). Organizational behavior. Forth Worth: The Dryden Press.

Watson, D., Clark, L. A., \& Tellegen, A. (1988). Development and validation of a brief measure of positive and negative affect: The PANAS scales. Journal of Personality and Social Psychology, 54, 1063-1070.

Wilderdom. (2007). What is personality? Retrieved November 2, 2008, from www.wilderdom.com/personality/L5-1WhatIsPersonality.html 